\title{
Building 3047 Hot Cell C Work Table Design
}

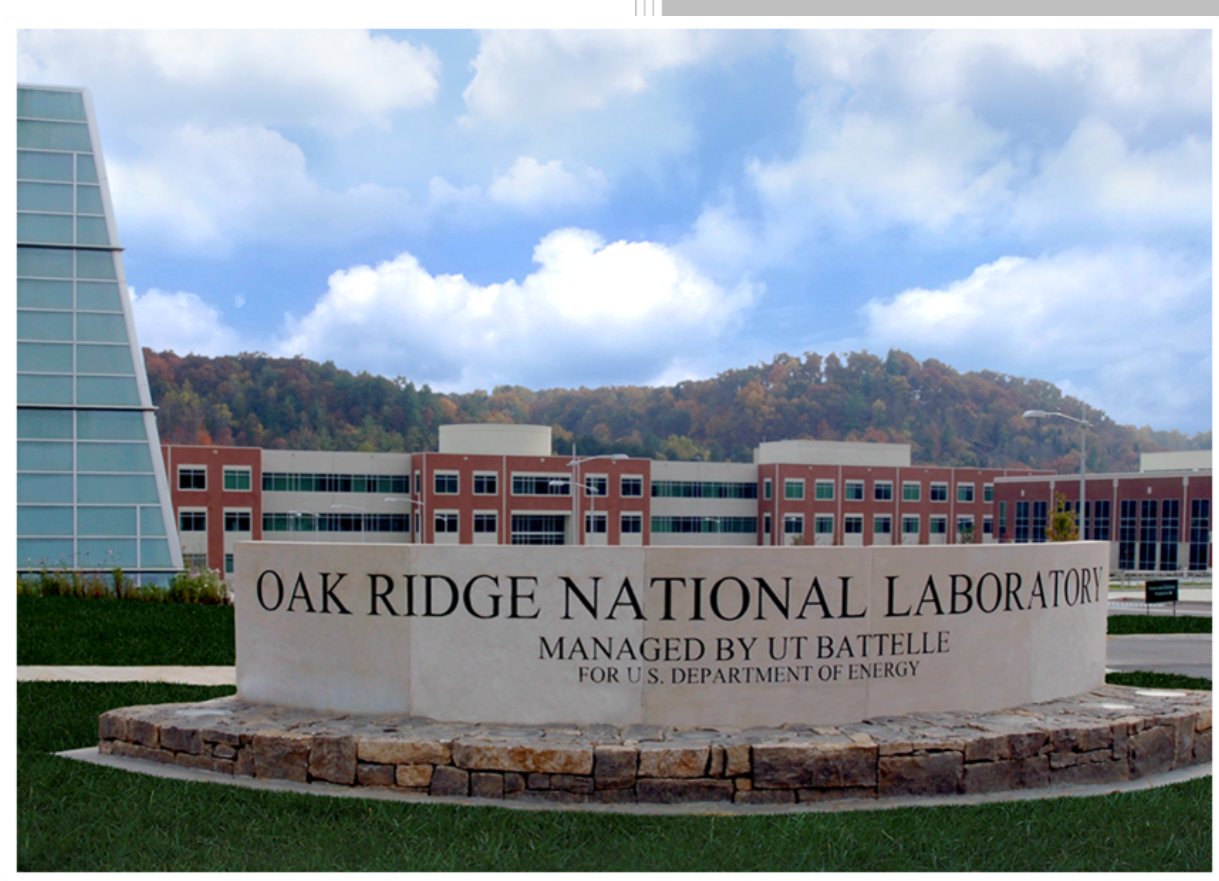

Dominic Giuliano

September 2018 


\title{
DOCUMENT AVAILABILITY
}

Reports produced after January 1, 1996, are generally available free via US Department of Energy (DOE) SciTech Connect.

Website www.osti.gov

Reports produced before January 1, 1996, may be purchased by members of the public from the following source:

\author{
National Technical Information Service \\ 5285 Port Royal Road \\ Springfield, VA 22161 \\ Telephone 703-605-6000 (1-800-553-6847) \\ TDD 703-487-4639 \\ Fax 703-605-6900 \\ E-mail info@ntis.gov \\ Website http://classic.ntis.gov/
}

Reports are available to DOE employees, DOE contractors, Energy Technology Data Exchange representatives, and International Nuclear Information System representatives from the following source:

Office of Scientific and Technical Information

PO Box 62

Oak Ridge, TN 37831

Telephone 865-576-8401

Fax 865-576-5728

E-mail reports@osti.gov

Website http://www.osti.gov/contact.html

This report was prepared as an account of work sponsored by an agency of the United States Government. Neither the United States Government nor any agency thereof, nor any of their employees, makes any warranty, express or implied, or assumes any legal liability or responsibility for the accuracy, completeness, or usefulness of any information, apparatus, product, or process disclosed, or represents that its use would not infringe privately owned rights. Reference herein to any specific commercial product, process, or service by trade name, trademark, manufacturer, or otherwise, does not necessarily constitute or imply its endorsement, recommendation, or favoring by the United States Government or any agency thereof. The views and opinions of authors expressed herein do not necessarily state or reflect those of the United States Government or any agency thereof. 
Fusion Materials for Nuclear Systems Division

\section{Building 3047 Hot Cell C Work Table Design}

Author

\section{Dominic Giuliano}

Date Published: September 2018

Prepared by

OAK RIDGE NATIONAL LABORATORY

Oak Ridge, TN 37831-6283

managed by

UT-BATTELLE, LLC

for the

US DEPARTMENT OF ENERGY

under contract DE-AC05-00OR22725 



\section{CONTENTS}

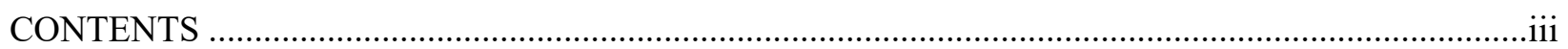

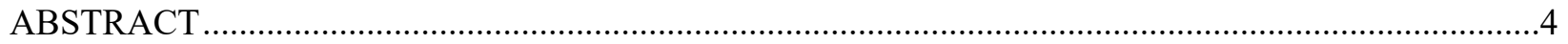



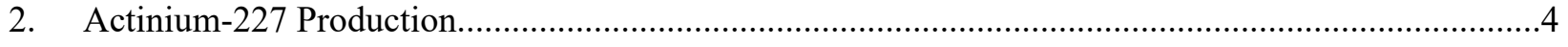

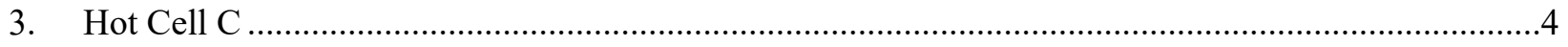

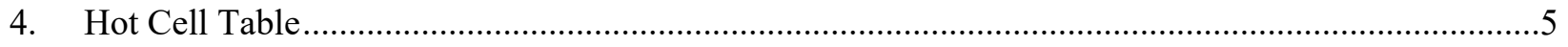

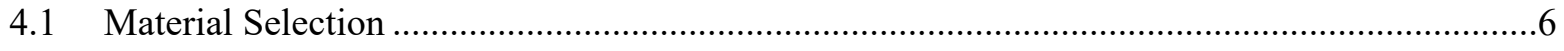

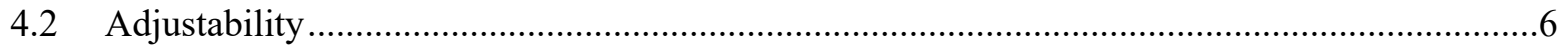

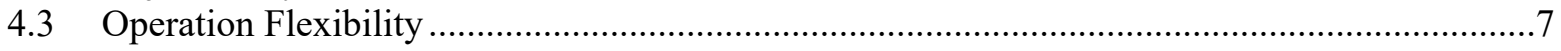

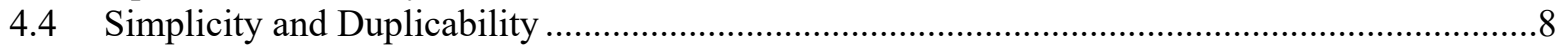

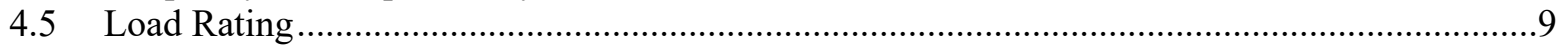

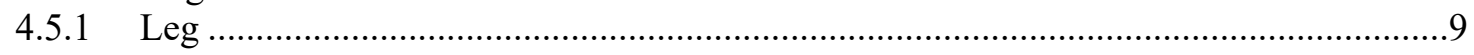

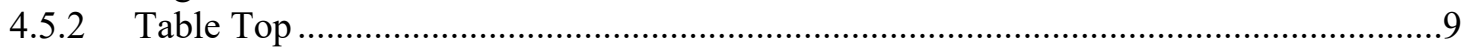






\begin{abstract}
To increase production capabilities of actinium-227, Oak Ridge National Laboratory is improving existing hot cell facilities in building 3047 where the feedstock is handled and processed. Current processing operations in hot cell $\mathrm{D}$ will be moved to the adjacent hot cell $\mathrm{C}$ after the addition of two new custom work tables. These work tables will enable additional production capacity which will help ORNL meet current commitments to the sponsor.
\end{abstract}

\title{
1. 3047 Facility
}

Building 3047, known as the Isotope Technology Building is the current facility being used to produce actinium-227 which is used by the customer for radio immunotherapy of bone metastasized prostate cancer. The building contains a bank of 4 hot cells (A through D as shown in Figure 1-1) each containing two through the wall master slave manipulators and are accessible through access plugs on the top of each hot cell and an operator accessible door in the back of each hot cell.

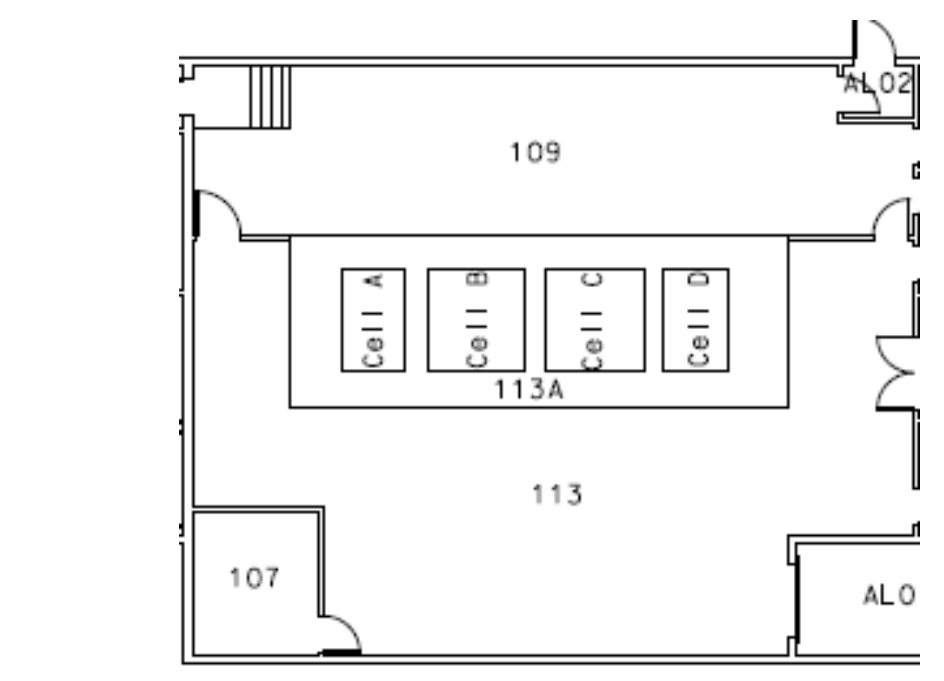

Figure 1-1 Plan view section of building 3047 showing row of 4 hot cells A through D

\section{ACTINIUM-227 PRODUCTION}

Actinium 227 has been produced using the hot cells in building 3047 to receive and process radioactive feedstock (radium chloride) from radium needles before going to the high flux isotope reactor (HFIR) for neutron irradiation. Currently all the pre-irradiation processing activities have taken place in hot cells D and $\mathrm{A}$. Hot cell $\mathrm{D}$ has been used to process the radium needles into usable radium that can be pressed with aluminum powder to make pellets, while hot cell A has been used for the final assembly and qualification of the HFIR irradiation capsules. To increase the current production of actinium 227, some processes currently in cell $\mathrm{D}$ will be moved to the larger cell $\mathrm{C}$ after tables have been fabricated to allow for the use of the hot cell $\mathrm{C}$ facility.

\section{HOT CELL C}

Hot cell $\mathrm{C}$ is a stainless steel lined hot cell with concrete and armored steel plating for neutron and gamma shielding. The hot cell is an 8' X 8' square with a sloped floor that allows for liquid to drain to a collection point 6 inches off the south east corner of the cell. An existing inter cell conveyor occupies 20$7 / 8$ " in front of the hot cell window from east to west wall, while the in-cell air treatment system against 
the west wall occupies an additional 20 inches (north to south) and 28 inches (east to west). Cell C, with these obstructions, allow for a workspace area of 75" X 65" as shown in Figure 3-1 which will be split into two adjacent tables.

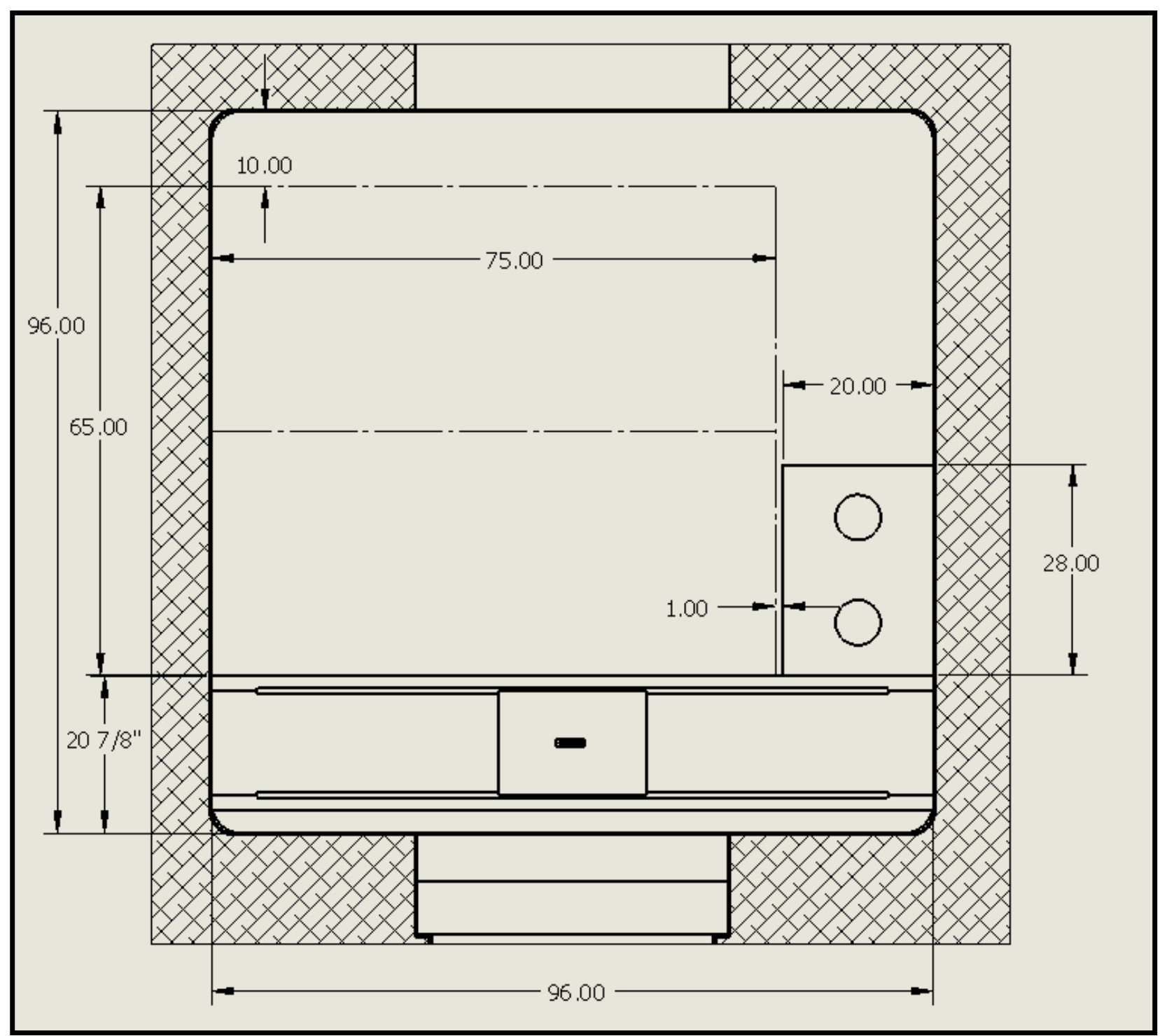

Figure 3-1Hot Cell C table area (Plan View)

\section{HOT CELL TABLE}

The hot cell work area will be achieved with the use of two adjustable work tables as shown in Figure 4-1 Design features include:

- Material Selection

- Adjustability

- Operation Flexibility

- Simplicity and duplicability

- Load Rating 


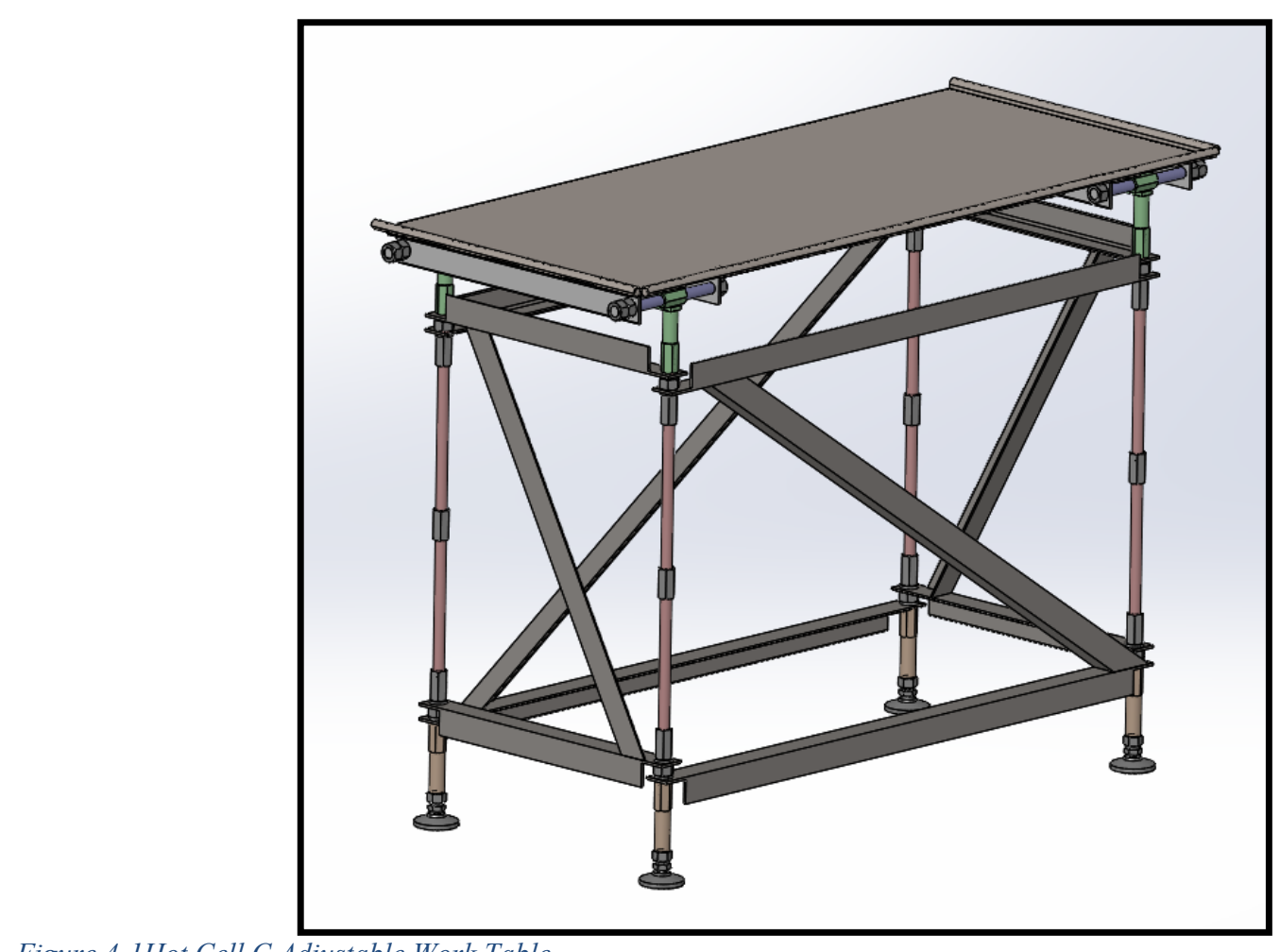

Figure 4-1Hot Cell C Adjustable Work Table

The hot cell work table will be a free-standing work table that will not require any additional or existing cell features for support. Each leg will have a leveling foot to accommodate for the sloped floor, and 9" of independent vertical adjustment. The spacing between the legs will be constant, but the table top will have 7" of adjustment from east to west. Cross bars and lock plates will be constructed in four weldments to ensure that the table will maintain maximum rigidity throughout its service life.

\subsection{MATERIAL SELECTION}

Planned service life, and hot cell operations have been considered for the selection of the table materials. Because of the likely use of nitic acid, in the operations planned for hot cell $\mathrm{C}$, the table will be made from 304 stainless steel or 18-8 stainless steel for maximum life and corrosion resistance. Acme rods, nuts, and couplings will be made from these similar materials, and thus there is a high change of galling occurring. To help prevent this, all threaded components will be coated with an anti-seize compound such as nuclear grade Neolube no. 1260.

\subsection{ADJUSTABILITY}

The cell $\mathrm{C}$ worktable is designed with adjustability in mind. Due to the geometry of the cell, the work table will be constructed by operators in the cell which will have existing obstacles and non-conformities that will have to be worked around during assembly. The table leg (Figure 4-2) is made from a 1"-6 lead screw to allow for vertical adjustment on the top and bottom. Acme nuts and couplings with the aid of lock washers will be used to fasten the leg locks and cross brace weldments. These features minimize the weight (man liftable) and aid in the ease of assembly. 




Figure 4-2 Table leg assembly

\subsection{OPERATION FLEXIBILITY}

For construction, and operation flexibility, the table top will be removable (see Figure 4-3). The removable table top design allows for the use of the space underneath the table if desired. A 57"X25" area is available to a depth of 50 inches for in cell storage or future operations if applicable. One potential use for the space is a creation of a shelving unit that can house rarely used items, so the table workspace is not infringed upon.

An additional design detail that adds to operation flexibility is the table top (see Figure 4-4). The table top has been designed with a rolled edge to provide a catch for liquid operations. Inside of this rolled edge will be 5-inch-long solid 3/4" diameter bars that are welded to the table. These bars provide structure for four $1 / 4$ "-20 through holes each allowing for many mounting configurations near the edge of the table. 


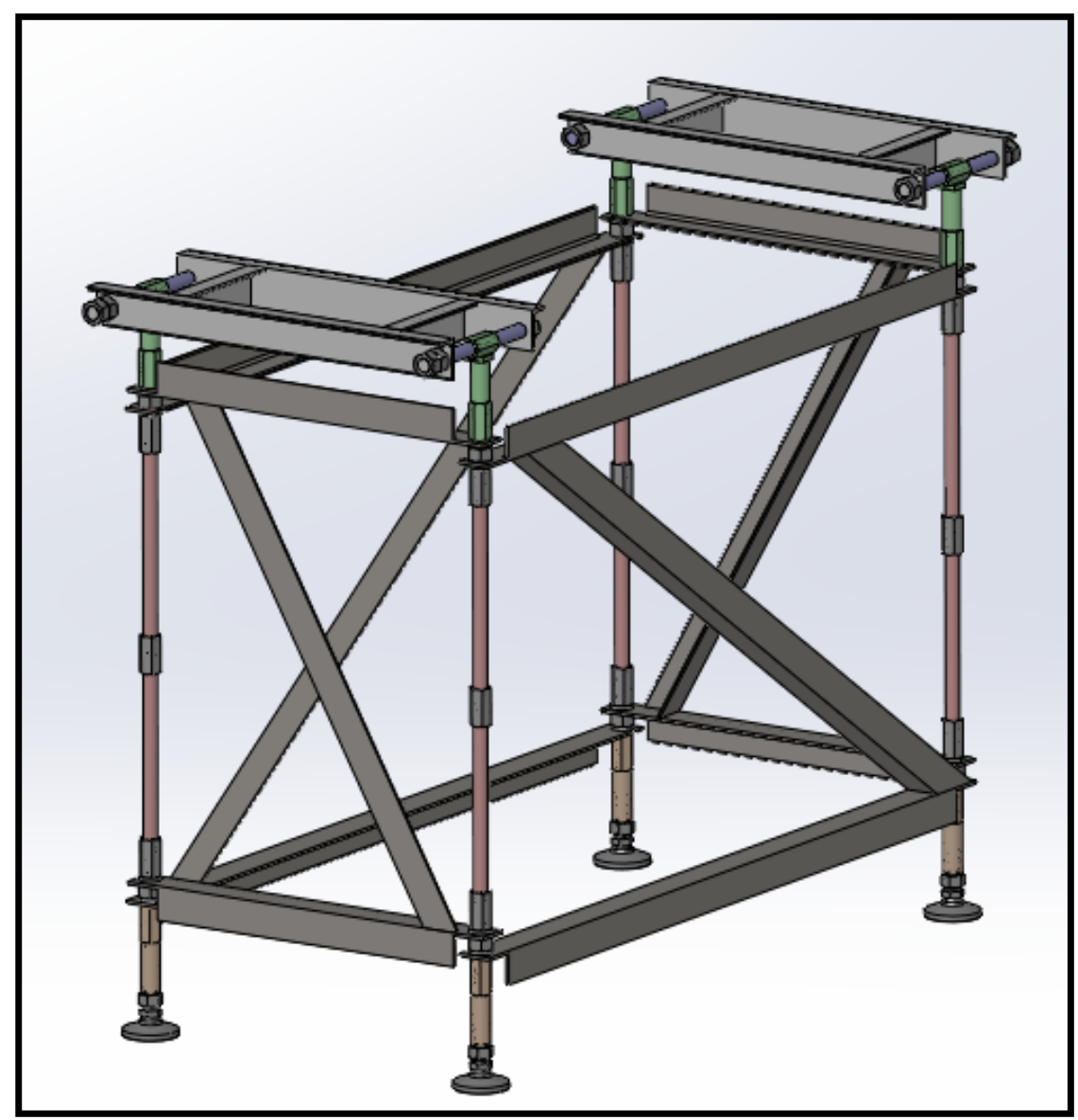

Figure 4-3 Table With table top removed

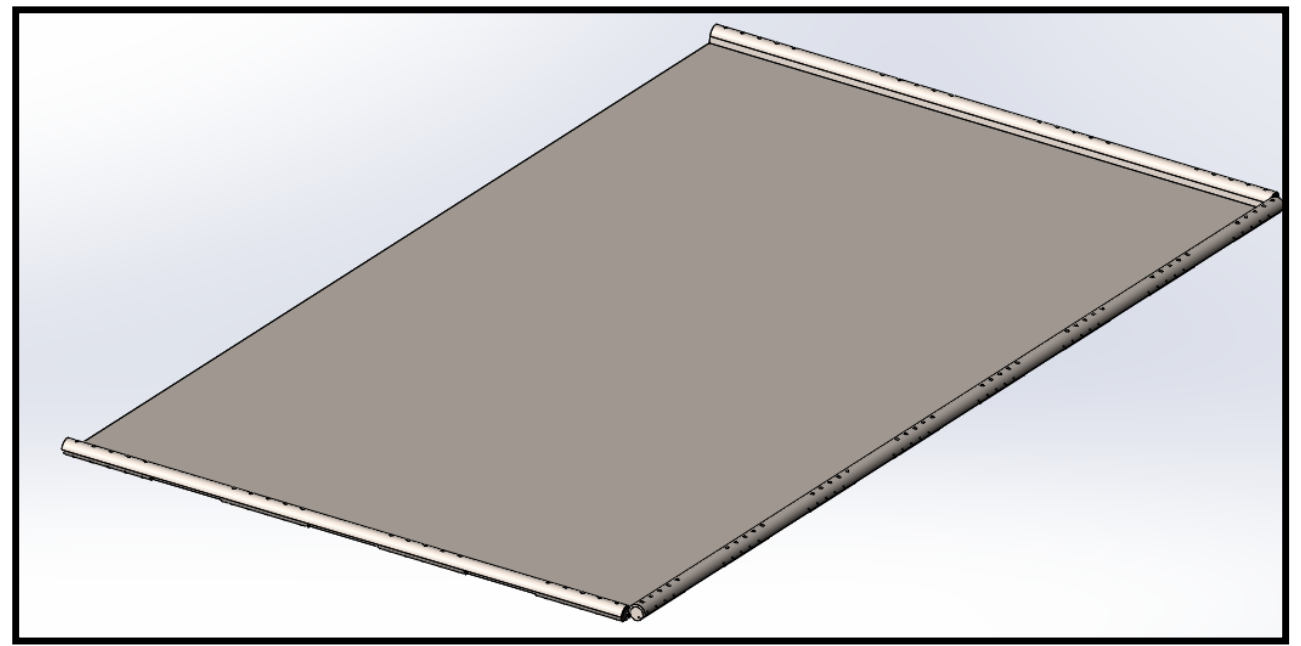

Figure 4-4 table top

\subsection{SIMPLICITY AND DUPLICABILITY}

Two of the most important design goals for this table is simplicity and duplicability. Care has been taken to design the table in a way that is simple (for cost and ease of construction), and duplicable. With an 
easily duplicable design, a standardized approach to future designs is possible. This allows for standardization over several hot cell facilities to occur. The benefit of standardization is time saved in operations and planning during future operation activities, ultimately saving costly mistakes and rework.

\subsection{LOAD RATING}

The table has been rated for 2,000 pounds total weight and for human load. The design case that was analyzed for human load is a 300-pound load over a 4"x4" area. This load and area correlates to an operator carrying equipment and standing on the ball of one foot in the table's area that is most susceptible to failure.

- For the load rating, a safety factor of 4 on yield strength was applied, and a deflection limit of $1 / 8$ " was set.

- For human load, a safety factor of 4 on yield strength was applied.

\subsubsection{Leg}

The table leg is a continuous 1"-6 ACME threaded lead screw. For a 2,000-pound load rating, two legs are assumed to carry the entire load and a safety factor of 4 is required. The unbraced length of the rod is 34 ", and using the minimum diameter of the acme rod (0.8") for the calculation of the second moment of inertia, the maximum load a leg can carry is

Where:

$$
P_{c r}=\frac{\pi^{2} E I}{l^{2}}=4,700 l b
$$

The young's modulus (E) for 304 stainless steel is $27.5 \mathrm{E} 6 \mathrm{psi}$, and the second moment of inertia (I) is $0.02 \mathrm{in}^{4}$.

This provides a safety factor of 4.7 for each leg.

\subsubsection{Table Top}

For the table top, two scenarios were analyzed.

- Maximum design load of 2,000 pounds evenly distributed between supports

- Postulated worst-case loading of 300 pounds in 4" X 4" area

\subsubsection{Maximum Design Load}

The maximum design load for the table is 2,000 pounds. For this analysis, the maximum design load was applied evenly over the area between the two supports. A finite element analysis was conducted with SolidWorks to determine the maximum resulting stresses and deflections. The maximum resulting stress is a stress concentration at the location of support and is 3,400 psi. This provides the table top with a safety factor of 8.8. The maximum resulting displacement is 0.0768 " which is within the design goal of 0.125 ". These results are shown in Figure 4-5 and Figure 4-6 respectively. 


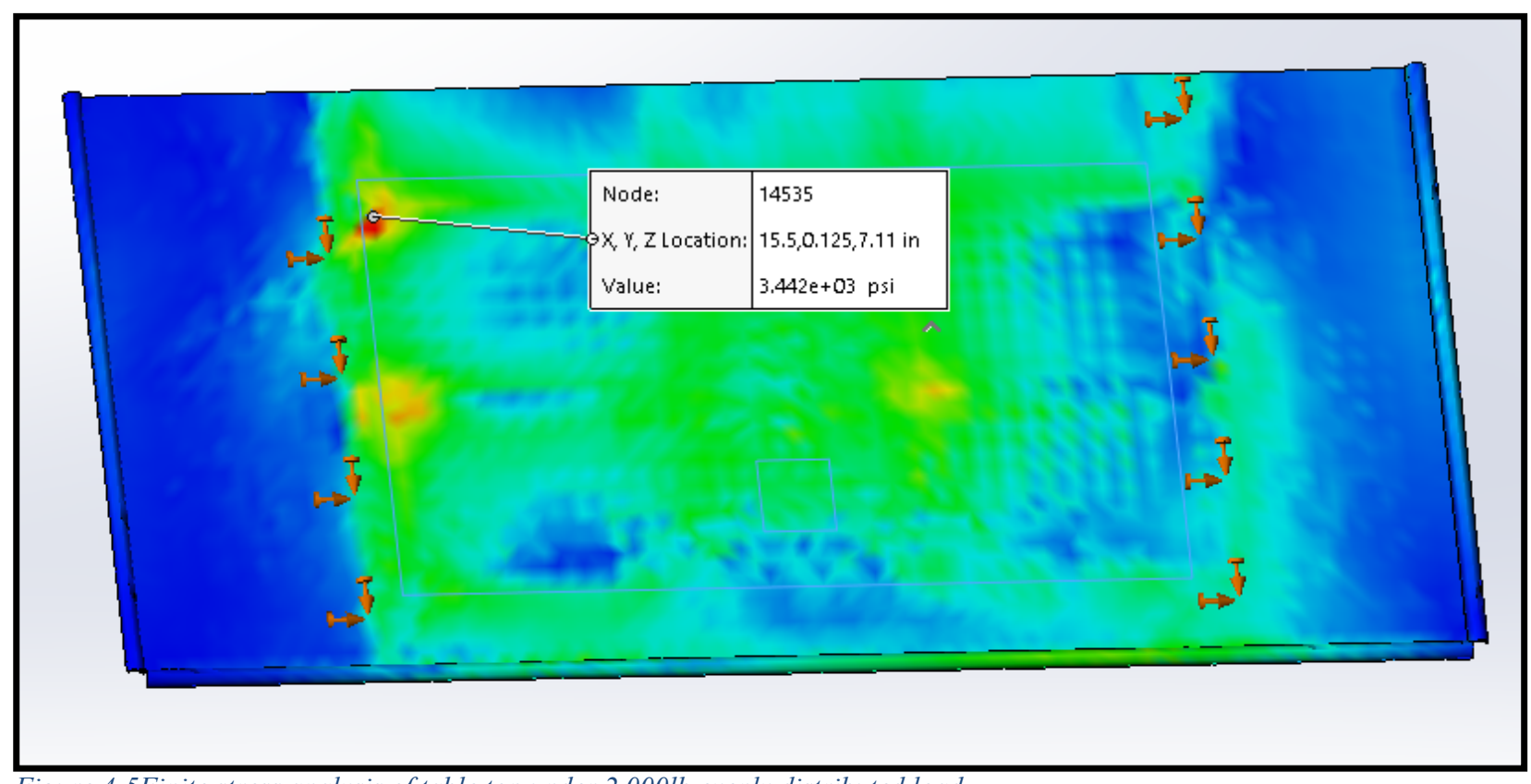

Figure 4-5Finite stress analysis of table top under 2,000lb evenly distributed load

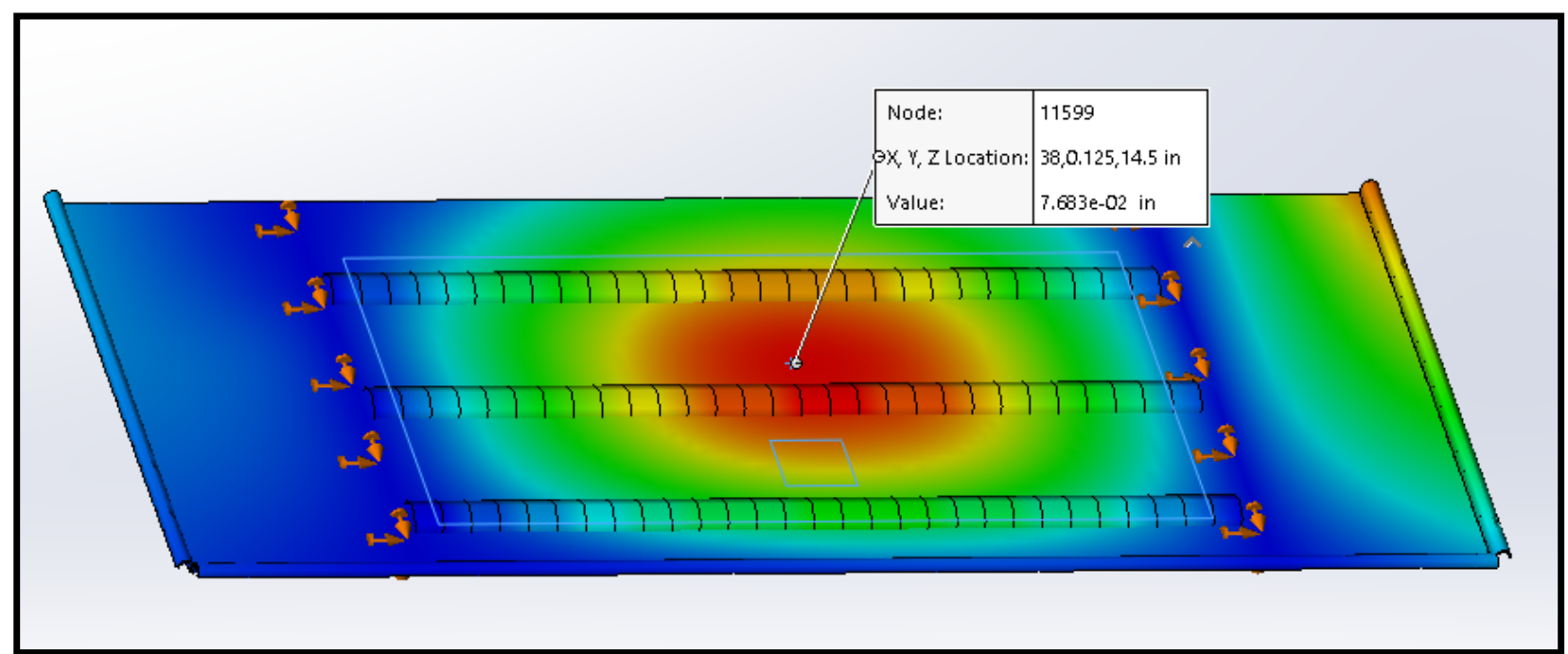

Figure 4-6 Displacement analysis of table top under 2,000 pound evenly distributed load

\subsubsection{Postulated Worst Case Loading}

The postulated worst case loading for the table top consists of a 300-pound force over a 4" X 4 " area in the most vulnerable location. This correlates to a combined weight of an operator with equipment standing on the ball of one foot. A finite element analysis was conducted with SolidWorks to determine the maximum stresses that occur during this postulated worst-case loading event. The finite element analysis is shown in Figure 4-7. 


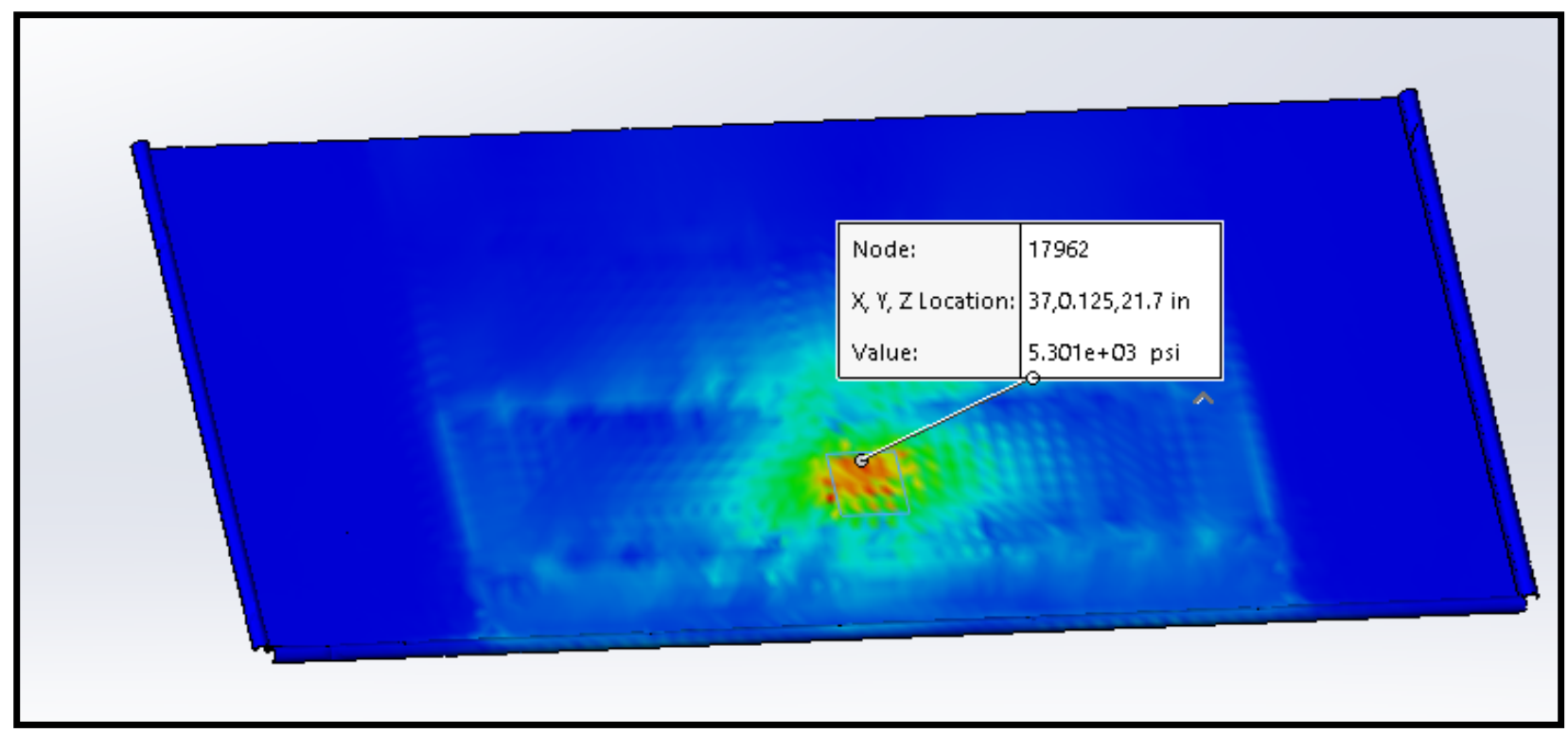

Figure 4-7 Finite Element Analysis of table top stress given a 300-pound load over a 4" X 4" area

As shown in Figure 4-7, the maximum stress generated in the table top during the postulated worst-case event is 5,300psi. Since the yield strength of the table top material (304 stainless steel) is 30,000psi, under the postulated worst-case event, the table top maintains a safety factor of 5.6.

\subsection{CONCLUSION}

This document presented the design of a hot cell table to be used in Hot Cell C in building 3047 known as the Isotope Technology Building. The table will allow for increased production capacity of actinium-227 which is currently in high demand. The table was designed with consideration to material selection, adjustability, operation flexibility, simplicity/duplicability, and load rating. The current table design meets all design requirements 